\title{
IDENTIFYING SOLUTIONS IN CREATING LEADER POTENTIAL IN AN ENTERPRISE
}

\author{
Katarzyna Grzesik \\ ${ }^{a}$ Wroclaw University of Economics, Wroclaw, Poland, \\ e-mail: katarzyna.grzesik@ue.wroc.pl
}

JOURNAL

OF POSITIVE

MANAGEMENT

Vol. 2, No. 1, 2011, pp. 25-36 (C) Copyright by Wydawnictwo Naukowe Uniwersytetu Mikołaja ISSN 2083-103X

\begin{abstract}
The aim of the article is to present the issues connected with developing leadership skills in a company. The article is a result of theoretical studies concerning the development of leaders in a company, as well as empirical studies carried out in Polish companies. The conditions in which companies currently operate and the changes they undergo, as well as growing requirements in terms of employees' competence, influence the growing significance of investment in company's human resources. Companies should also notice and shape leadership potential of their employees. In a company we can distinguish between natural-born leaders, with inherent leadership skills, and shaped leaders, who have developed their skills. However, leaders who are just emerging or individuals with leadership potential which can be developed should be equally important for a company. In the process of leader development companies can use a variety of methods, practically applied in different combinations, depending on the needs.
\end{abstract}

Keywords: leadership, leader, leader development

Paper type: Research paper

\section{Introduction}

A company's potential should be viewed as a multi-dimensional category, which in a variety of ways concerns certain possibilities founded upon particular skills, competences and abilities included among the assets owned, as well as skilful use of the environment's assets (Lichtarski, 2005: 156). An organization's most valuable asset is believed to be people with a certain potential manifested by their efficient performance, as well as their skills and potential. A company's human potential then, are its employees and their attributes. According to M. Gableta, competences including knowledge, predispositions, skills and internal motivation should also be treated as part of the potential. An employee's internal motivation means his life goals, maturity, aspirations, strength and stability of his endeavours and work enthusiasm (Gableta 2006: 19). Predispositions (abilities) connected with the potential within the employees require certain actions aimed at their proper recognition and shaping. Changes which comprise the conditions of a company's functioning, as well as growing requirements concerning employees' 
IDENTIFYING SOLUTIONS

Katarzyna Grzesik competences bring about the increasing significance of investment in employees' development. That is why employee development, viewed as an important investment, is a tool by means of which an organization aims to improve current efficiency and shape the employees' potential. (Sienkiewicz, 2010: 133).

J.P. Kotter emphasizes that 'nowadays leadership skills have become much more important than they used to be 50 years ago, when the world was changing at a much slower pace. Without good leadership on various levels of management it is difficult to deal with numerous difficulties, which tend to appear out of the blue' (Na czym..., 2004: 28). It means that companies should notice and shape the leadership potential of their employees.

The aim of the article is to describe the issue of leader creation in companies. The article presents the first stage of empirical studies* carried out in Polish companies concerning the development of leadership skills, as well as the results of theoretical studies.

\section{Leadership can be learned}

Can leadership be learned? Dozens of years ago it was claimed that leadership skills are innate and unchangeable, and that one is a leader by being born one. However, the statement must be considered incorrect, as many people may have some predispositions to be a leader, which should be discovered, with leadership skills to be built up upon them (see: Adair, 2007: 41). 'The belief that leadership skills can and should be taught grew stronger with time; it was less evident, however, how it should be done' (Adair, 2010: 27).

It should be considered merely a myth that few people can understand what leadership is, as 'leadership is neither a gene or a secret code beyond the reach of ordinary people'. The truth is that leadership a set of skills and competences which is possible to observe (...). Each of the skills, as long as there is sufficient motivation and will, can be enhanced, perfected, developed through practice, training, feedback and role models' (Kouzes and Posner, 2010: 303). This means that valuable leaders are not individuals of extraordinary skills, but descend from among ordinary people who are conscious of their knowledge, make reasonable decisions and accept the pressure of changes. Organizations can recruit their leaders from outsider, or shape them within their structure. Recruiting leaders from outside is a quick way to obtain trained staff with fresh ideas, without the need to create costly internal training programs. However, the main drawback of refraining from developing leaders in an organization is the potential drop in morale among those who were rejected as such, as well as temporary decrease in

* The study conducted within the confines of promoter research grant entitled Identification of solutions applied by Polish companies in the field of leaders' development and assessment of their application, Project manager: dr hab. Grażyna Osbert-Pociecha, prof. UE, research project No. N N115 002538. 
productivity in the period when the new leader learns his role in the context of a given organization. Developing leaders within an organization, despite the fact can prepare the next generation of leaders, suitable for its culture and strategy. Secondly, an organization has a bigger control over the supply of leaders with suitable qualities, allowing for faster implementation of a given strategy (see: Pernick 2004: 429-430).

Having worked with thousands of people with strong leadership aspirations, J.C. Maxwell believes that in terms of leadership skills people can be divided into four categories: natural leaders, shaped leaders, shaping leaders and potential leaders (Maxwell 1994, pp 11-12). Particular categories have a set of specified characteristics which, except for the ones who have innate leadership skills, can be acquired (see Table 1) .

\begin{tabular}{|c|c|}
\hline Categories & Characteristics \\
\hline Natural leaders & $\begin{array}{l}\text { - Have inherent leadership skills } \\
\text { - Observed role models of leadership for their whole lives } \\
\text { - Developed their leadership skills consciously } \\
\text { - Have self-discipline necessary for great leaders }\end{array}$ \\
\hline Shaped leaders & $\begin{array}{l}\text { - Observed role models of leadership for most of their lives } \\
\text { - Developed their leadership skills consciously } \\
\text { - Have self-discipline necessary for great leaders }\end{array}$ \\
\hline Shaping leaders & $\begin{array}{l}\text { - Have recently encountered role models of leadership } \\
\text { - Learn leadership skills } \\
\text { - Have self-discipline necessary for great leaders }\end{array}$ \\
\hline Potential leaders & $\begin{array}{l}\text { - Have encountered no or very few role models of leadership } \\
\text { - Do not learn leadership skills, or do so to a limited extent } \\
\text { - Want to become leaders }\end{array}$ \\
\hline
\end{tabular}

Table 1.

Leader categories according to J.C. Maxwell

Source: Maxwell (1994: 11-12).

In a company we can thus distinguish both natural leaders with inherent leadership predispositions, as well as shaped leaders, who have developed their skills. However, leaders who are in the shaping stage or have leadership potential which can be developed, should be equally important for a company.

In order for the initiative of leader development to be successful for a company, it should specify the goals which are to be achieved through it. From the perspective of leader development in a company, we can distinguish the following general categories of goals (Moore, 2004, pp 8-9):

- $\quad$ creating a strong group of talented leaders, which means people who can in the near future take control of the organization. It is the process of 
IDENTIFYING SOLUTIONS

Katarzyna Grzesik developing within a company leaders who are well-suited to particular business, in order to maintain its continuity;

- transforming a business, which means preparing the people who would be capable of making significant changes in the company's functioningleaders of changes, who will be able to take charge of a given change and encourage other company's employees to it;

- $\quad$ increasing the leaders' effectiveness, which means developing the skills of present leaders, detecting deficiencies or needs resulting from the changes taking place inside or around a company;

- help in career development, which means preparing people who will serve as support for other employees of the company.

Before taking action aimed at developing leaders, each company should specify the essence of leadership in the context of its activities. Precise understanding of the essence of leadership is important due to the fact that it everybody talks about it, but means something different, it is difficult to formulate the catalogue of demands. The lack of clarity can have disastrous influence on the programs of managers' qualifications development' (Na czym ..., 2004: 28). At the same time 'it is wrong to assume that everything a company needs is a good strategy leader in charge. The secret of success in business is excellent leadership at all three levels' (Adair, 2010: 12).

\section{Solutions in developing leadership skills in companies}

The data presented is a result of the study carried out in Polish companies, which meant companies based in Poland and operating under Polish legislation. The study was carried out by means of a survey and is the first step in the studies carried out by the author concerning the identification of solutions used by Polish companies to develop leaders.

For the purpose of solving the problem researched the author assumed the following definition of leader and leader development. The former is meant by an individual in possession of skills and abilities which make him capable of commanding a group of people in a way which allows it to successfully carry out its goals, make a cohesive team and cater the needs of each of its individual members. Leader development is understood as a set of actions aimed at increasing one's knowledge, skills and abilities, as well as experiences connected with performing the role of leader in a company (see: Day, 2000, pp 583-584).

The study was carried out in 50 companies, among which, according to the number of employees, there were 13 large companies, 7 medium ones, 17 small ones and 13 micro-companies. Among the 50 companies there were ones from various business areas, such as telecommunications, power industry, food industry, consulting, training, electronics, electrical engineering, paper industry, IT and construction. Over $50 \%$ of the companies studied declared taking actions 
aimed at leader development (see Figure 1), with the data for specific company type being $100 \%$ of large companies, $86 \%$ medium companies, $12 \%$ small ones and $38 \%$ of micro-companies.

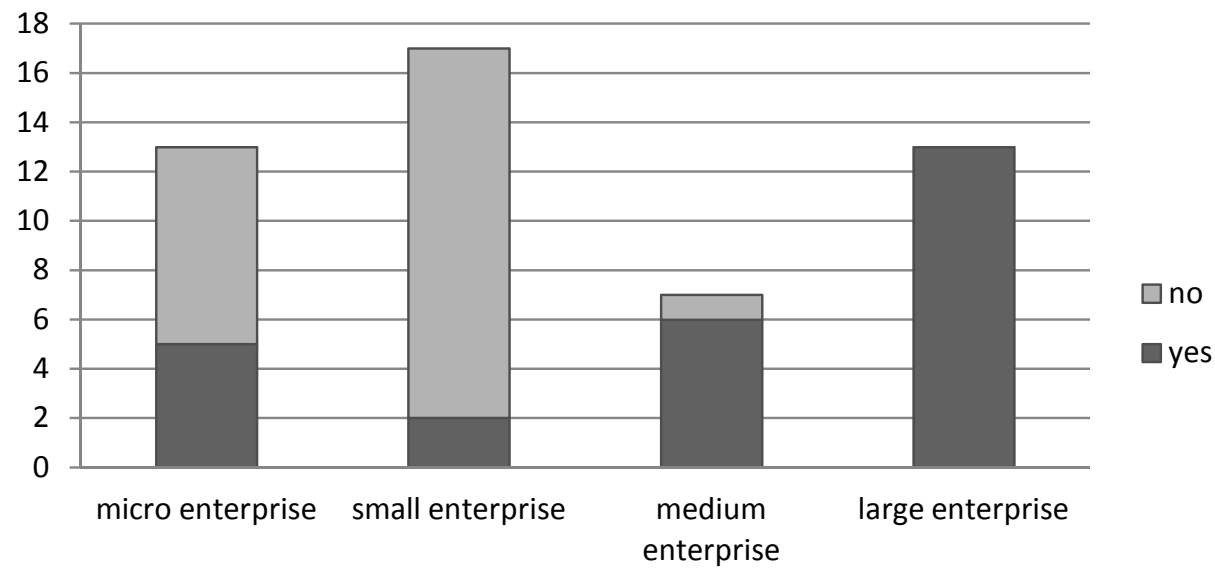

number of enterprises

Figure 1. Companies declaring taking action aimed at leader development

Among the micro and small companies the actions aimed at developing leader skills are mostly taken by the ones from the consulting and training branch. The employees which are subjected to them are mostly top managers and specialists. The actions concern both those who already perform the roles of leaders, as well as those who are to or may perform such role in the future. However, along with the expansion of a company, the actions aimed at developing leader skills are extender to all levels of management. The companies who take action in leader development evaluate them as:

- hardly developed- $31 \%$ of companies,

- $\quad$ sufficiently developed $54 \%$ of companies,

- well-developed- $15 \%$ of companies.

Among the reasons which made the companies take action in leader development the aspects of preparing future managing staff and keeping the most talented works in a company were most commonly highlighted (see Figure 2). Next ones on the list were the need of improving the employees' competences and the company's functioning. The companies studied also pointed to the following reasons: the objectives of human resources strategy, the need to constantly implement changes and difficulties with recruiting leaders from outside. In large companies the dominant reasons for taking action in leader development 
IDENTIFYING

SOLUTIONS

Katarzyna Grzesik

Figure 2.

The reasons for taking action in leader development

Source: own research. were the need to prepare future managing staff and keeping talented employees in a company, whereas micro and small companies, apart from improving the competence of managing staff, pointed to the need of implementing constant changes.

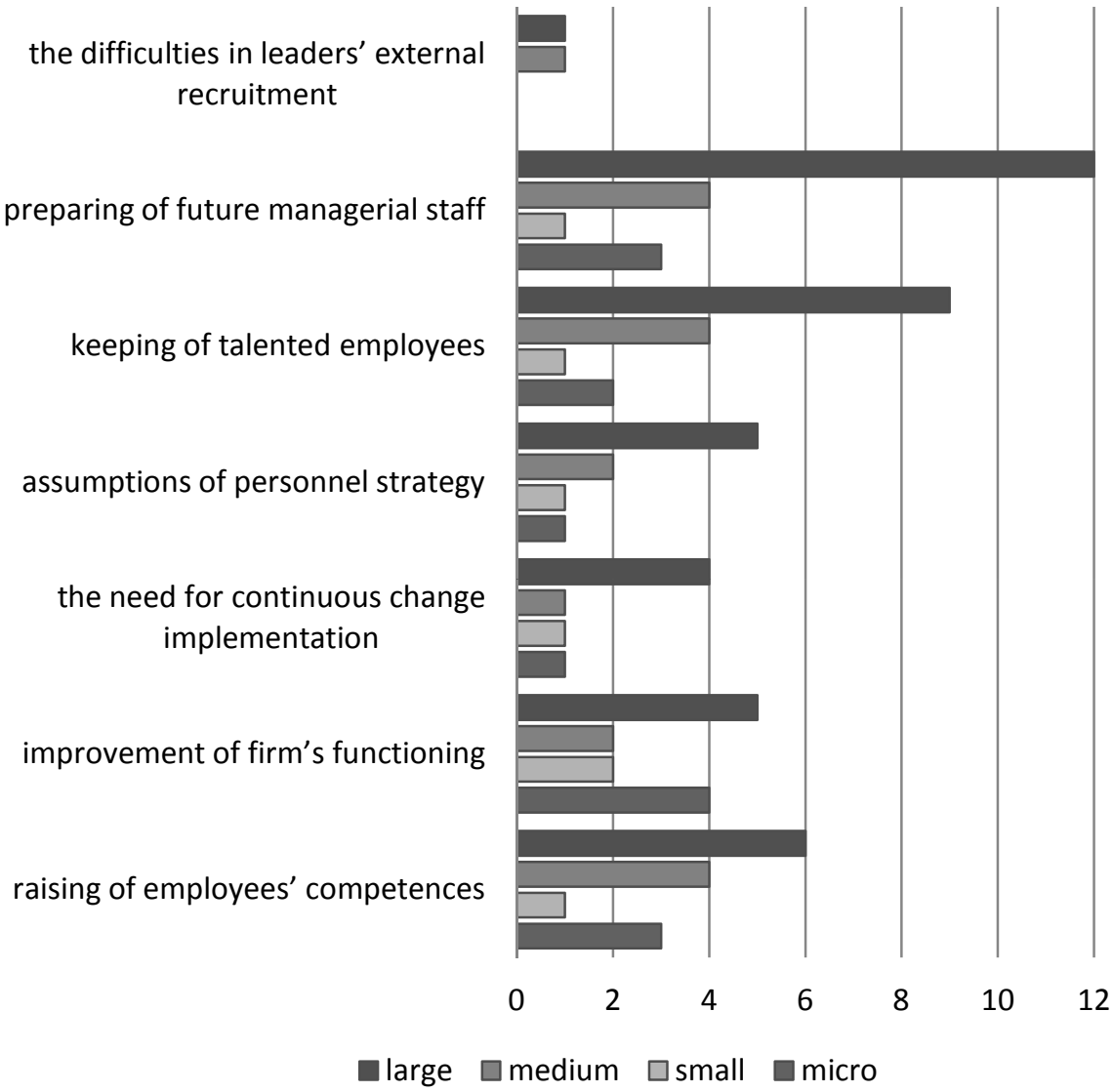

In the companies studied the identification of people who are prepared for the role of leader is carried out mostly by means of evaluation of the objectives set and the way of behaving in situations crucial to one's performance at a given position (see Figure 3). In addition, the companies studied make use of periodical evaluations, interviews and talent reviews. In micro and small companies the top managers are usually included into development programs due to their position. In large companies, on the other hand, periodical evaluations are more important, as well as reviews of the talents available. 


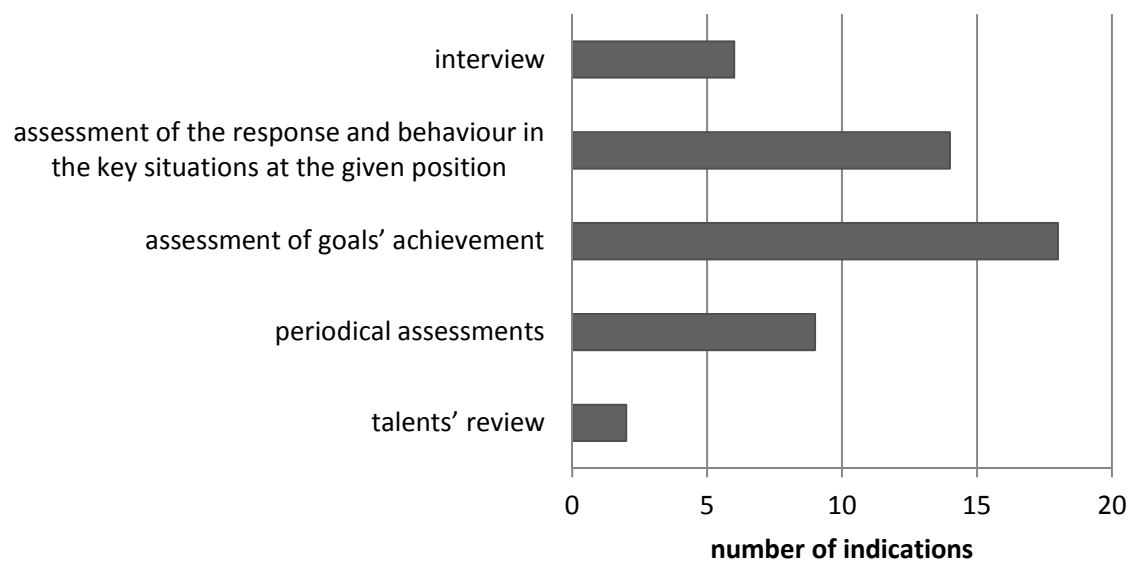

Figure 3.

The ways of identifying individuals with leader potential in the companies studied Source: own study.

In the course of leader development companies have a wide range of action available (see Figure 4 and Table 2)

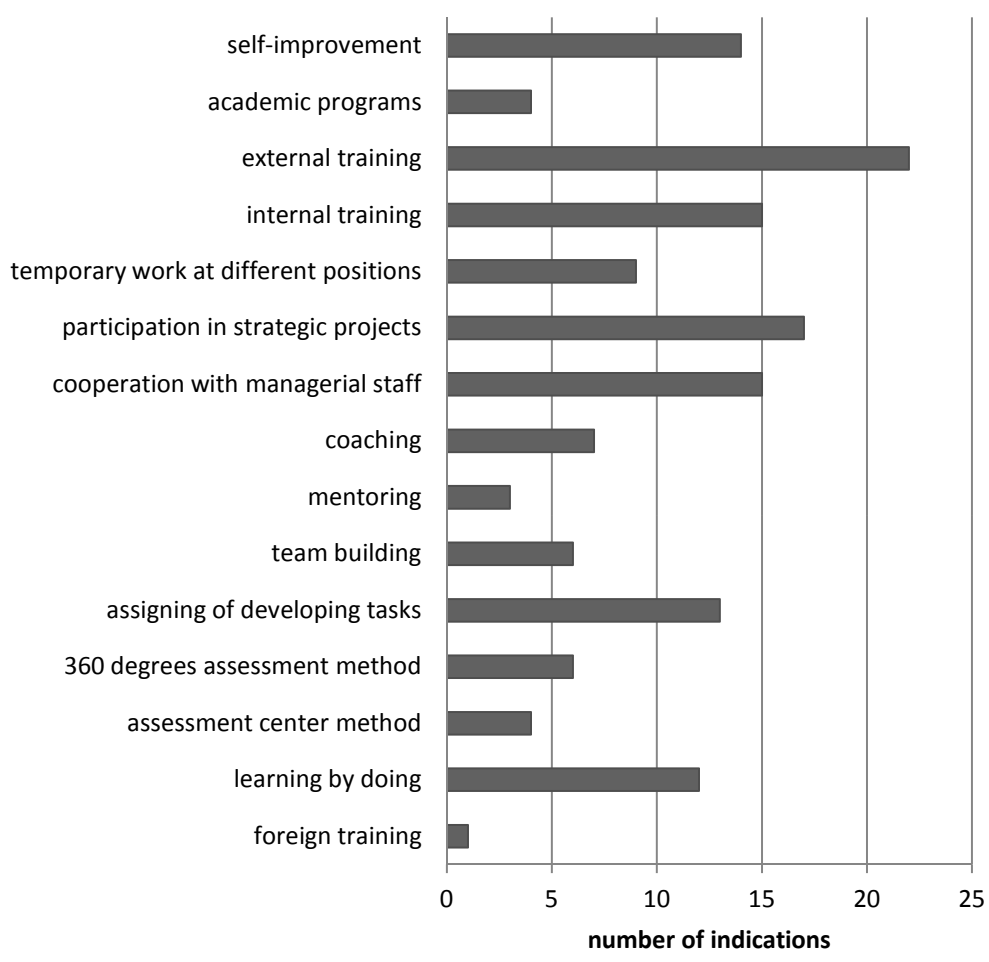

Figure 4.

Methods used in leader development in the companies studied Source: own study. 
IDENTIFYING SOLUTIONS

Katarzyna Grzesik

Table 2.

Number of methods pointed as the ones used in leader development in the companies studied according to the company size

Source: own study.

\begin{tabular}{|l|c|c|c|c|}
\hline \multicolumn{1}{|c|}{ Method } & Micro & Small & Medium & Large \\
\hline Self-mastery & 3 & 2 & 1 & 8 \\
\hline Academic programs & 0 & 0 & 0 & 4 \\
\hline External trainings & 4 & 2 & 4 & 12 \\
\hline Internal trainings & 1 & 2 & 4 & 8 \\
\hline Periodical work on various positions & 2 & 1 & 1 & 5 \\
\hline Participation in strategic projects & 2 & 0 & 4 & 11 \\
\hline Cooperation with the managing staff & 1 & 2 & 4 & 8 \\
\hline Coaching & 0 & 0 & 2 & 5 \\
\hline Mentoring & 0 & 1 & 0 & 2 \\
\hline Team-building & 3 & 1 & 2 & 0 \\
\hline Assigning developmental tasks & 3 & 1 & 3 & 6 \\
\hline 360 degree feedback & 0 & 0 & 2 & 4 \\
\hline Assessment Centre method & 0 & 0 & 0 & 4 \\
\hline Learning through action & 1 & 1 & 3 & 7 \\
\hline Practice abroad & 0 & 0 & 0 & 1 \\
\hline
\end{tabular}

The most widely used development methods are external trainings, participation I strategic projects and cooperation with the managing staff. Apart from external trainings, companies also carry out internal ones. Other significant factors are assigning developmental tasks, working in various positions, self-mastery, participation in overseas projects and team-building. On the other hand, mentoring and coaching, as well as academic programs, are used less frequently. Companies use various combinations of the abovementioned methods. In large companies the actions are usually cyclical, whereas in small companies the actions taken are mostly extemporary. Among the companies studied 50\% pointed to the link between leader development and human resources strategy. Only $38 \%$ of the companies studied admits having formalized leader development programs. At the same time, some of them declare the need to make such formalization.

The companies studied also cooperate with outside institutions in leader development (50\% of the companies studied declared to be doing so), such as training and consulting companies, as well as companies specialized in leader development.

Implementing leader development causes a number of limitations. The companies studied pointed to some most important sources of inhibition (see Figure 5). 
the difficulties in keeping of talented employees

the lack of employees' interest in development

the lack of employees skilled appropriately for development

the lack of top management support the lack of leader profile determination in a company

the lack of favourable organizational culture

the lack of knowledge regarding the means of leaders' development

the lack of appropriate means for development of leader skills

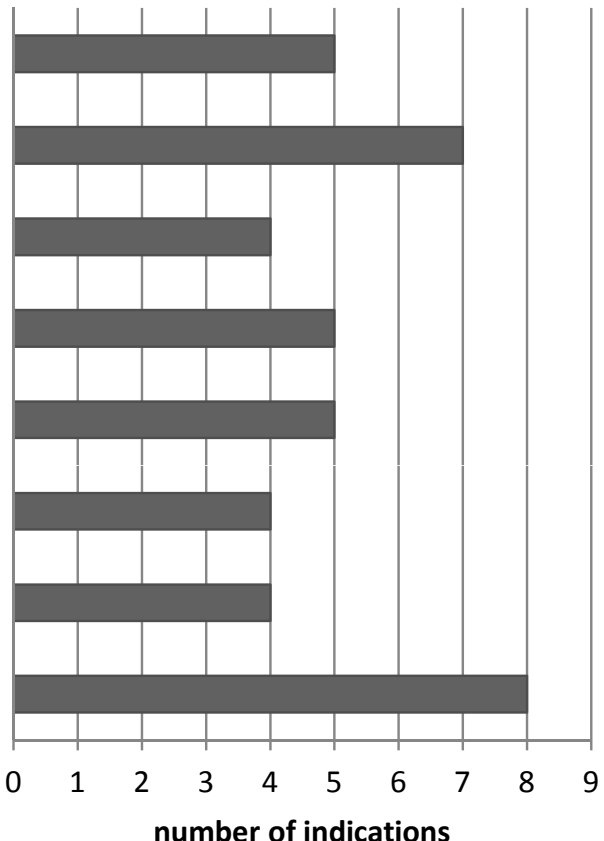

number of indications
IDENTIFYING SOLUTIONS

Katarzyna Grzesik

Figure 5.

Barriers in leader development in the companies studied

Source: own study.

Among the barriers pointed, we can find both those which are caused by the company, and by the employees. On the company's side, the most important ones were: lack of sufficient funds for developmental actions, lack of support from the top managers, and no specifications for the leader's profile. The companies also point to the lack of appropriate culture and knowledge concerning the ways of company's development. In terms of employees, on the other hand, the factors mentioned were: lack of interest from the staff concerning leader skills development, difficulties in keeping talented employees, and lack of employees with leader skills.

At the same time the companies pointed to the factors facilitating proper developmental actions in terms of leadership (see Figure 6). The most prominent factor mentioned was the support from senior managers, as well as favourable organizational culture. Next on the list was availability of sufficient assets and resources. Another important aspect was employees' dedication, appropriate recruitment and selection process, providing leaders with feedback, and creating human resources strategy aimed at employees' development, including leader skills. 
IDENTIFYING

SOLUTIONS

Katarzyna Grzesik

Figure 6.

Key factors for proper leader skills development in the companies studied

Source: own study.

\section{Figure 7.}

The need of developing leader skills according to the companies studied

Source: own study.

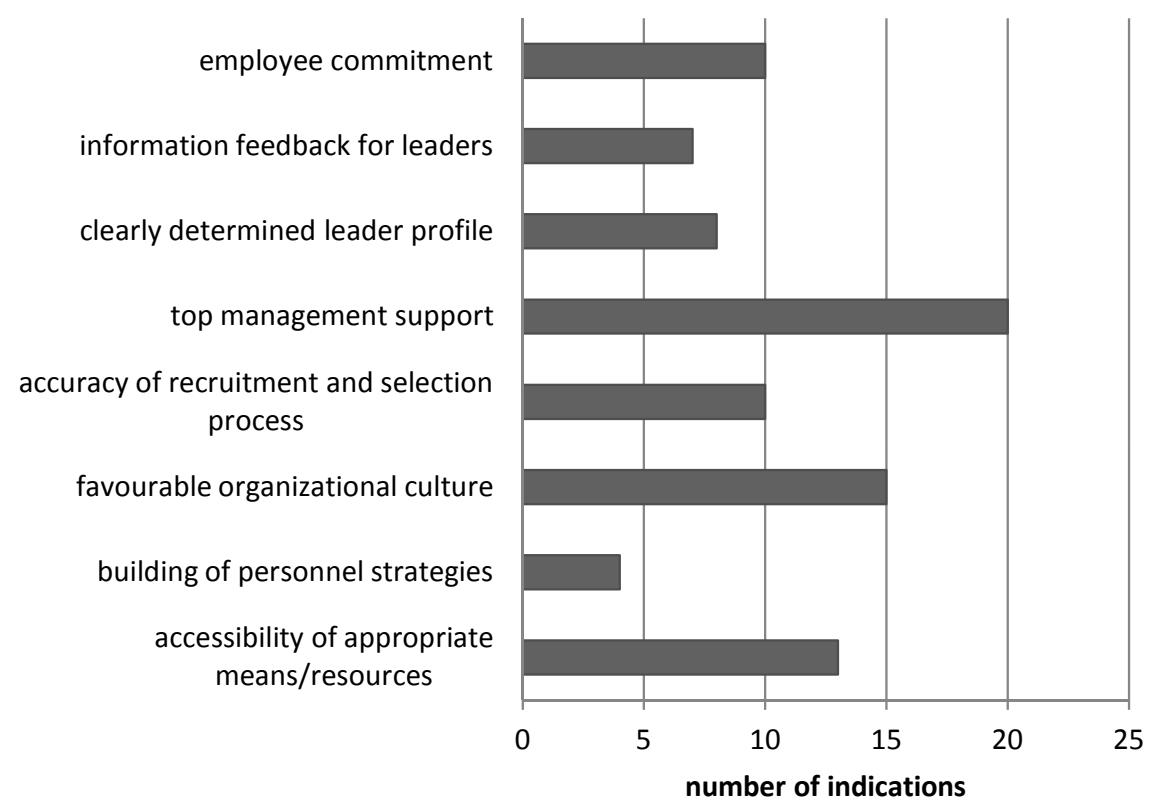

The companies studied believe that nowadays it is necessary to develop leader skills among the staff (see Figure 7) $76 \%$ of them pointed to the need of such development, with only two companies declaring that companies should not develop leader skills among its employees. $20 \%$ of the companies studied have not formed an opinion on the matter.

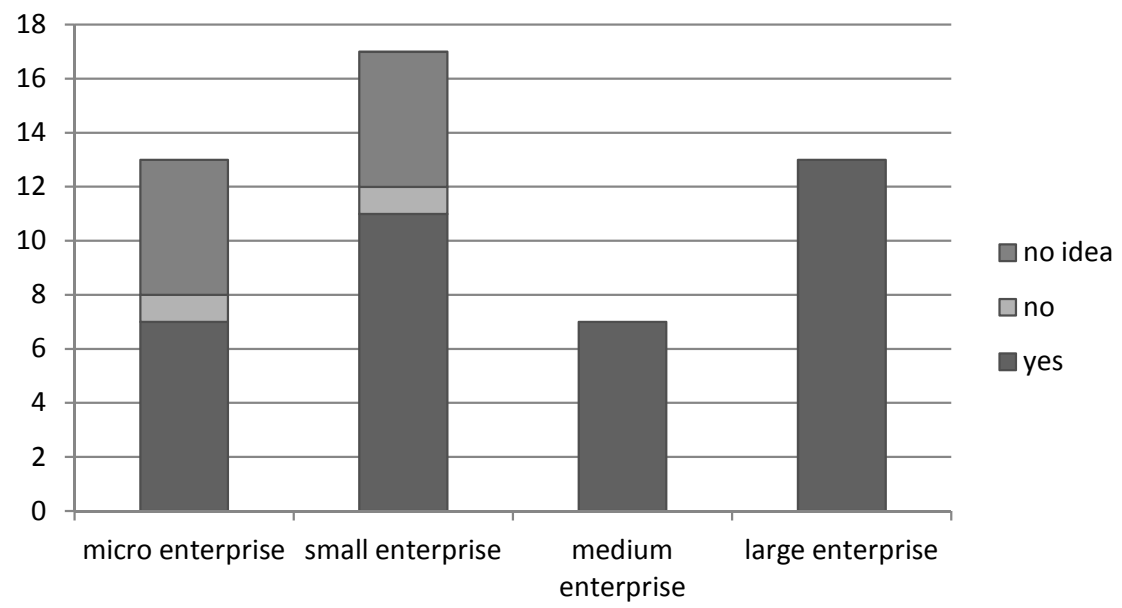


It should also be emphasized that among the companies which are currently not undertaking development al action concerning leadership, $12 \%$ declare the need to be doing so in the future. Over $60 \%$ however, have not yet considered the issue of taking such action.

\section{Conclusion}

According to the findings by A. Pocztowski, since 'people are genetically equipped in a set of features and characteristics which can, but do not have to be developed, we can conclude there is a need to invest in their development' (Pocztowski, 2007: 274). Employee development seems to be a strategic necessity, rather than a company's free choice. It should also be emphasized that one of the crucial aspects of a company's functioning is leadership and the set of features and skills connected with it. Since natural leadership is incapable of catering for the company's existing needs, it is necessary to take action involving the development of skills needed to perform the role of a leader within a company's own structure by selecting those individuals who have the right predispositions and subjecting them to leader development programs.

The research points that within the sample of companies studied there are actions involving leader skills development. Developmental actions involve both the employees who already perform the leader role, as well as those who are supposed to perform it in the future. Along with the company's growing size, all levels of management are involved in this kind of actions. Companies can use various methods in the course of their leader development process. In practice, many of them are used in various combinations, depending on the existing needs. The actions taken in most micro- and small companies are usually of extemporary nature, whereas in large companies they tend to be periodical and more formalized. In the course of developing leader potential among employees, companies cooperate with outside institutions. At the same time, external trainings are the method most frequently used for developing leader skills in the companies studied. According to the companies studied, the main inhibition in development is the lack of resources. On the other hand, the most basic condition for effective development of leader potential was believed to be the support from top managers and favourable organizational culture.

\section{References}

Adair, J. (2007), Rozwijanie umiejętności przywódczych, ABC a Wolters Kluwer business, Kraków.

Adair, J. (2010), Kształtowanie liderów. Siedem zasad rozwijania zdolności przywódczych, Oficyna a Wolters Kluwer business, Warszawa.

Day, D.V. (2000), "Leadership development: a review in context", Leadership Quarterly, Vol. 11, No. 4. 
IDENTIFYING SOLUTIONS

Katarzyna Grzesik
Gableta, M. (Ed.) (2006), Potencjat pracy w przedsiębiorstwie, Wydawnictwo Akademii Ekonomicznej we Wrocławiu, Wrocław.

Kouzes, J.M., Posner, B.Z. (2010), Przywództwo i jego wyzwania, Wydawnictwo Uniwersytetu Jagiellońskiego, Kraków.

Lichtarski, J. (Ed.) (2005), Podstawy nauki o przedsiębiorstwie, Wydawnictwo Akademii Ekonomicznej we Wrocławiu, Wrocław.

Maxwell, J.C. (1994), Być liderem czyli jak przewodzić innym, MEDIUM, Warszawa.

Moore, J. (2004), "Where do you start with leadership development?", Development and Learning in Organizations, Vol. 18, No. 5.

„Na czym polega istota przywództwa” (2004), Zarządzanie na Świecie, No. 11.

Pernick, R. (2001), "Creating a Leadership Development Program: Nine Essential Tasks", Public Personnel Management, Vol. 30, No. 4.

Pocztowski, A. (2007), Zarządzanie zasobami ludzkimi. Strategie, procesy, metody, PWE, Warszawa.

Sienkiewicz, Ł. (2010), „Rola szkoleń i rozwoju w budowaniu innowacyjności pracowników i przedsiębiorstwa", in: Borowska, S. (Ed.), Rola ZZL w kreowaniu innowacyjności organizacji, Wydawnictwo C.H. Beck, Warszawa. 